\title{
Yachting - Nautical Tourism in the 2020 Moroccan Tourism Strategy: An Analysis of the Models of Saïdia and Bou-Regregmarinas
}

\author{
By Mohamed Boukherouk ${ }^{*}$
}

\begin{abstract}
In Morocco, yachting tourism is an important component of the 2020 tourism vision. Several marinas projects have been launched since 2000 to achieve the Moroccan tourism vision goals, orientated towards yachting/nautical tourism. Indeed, both tourism strategies 2010 and 2020 gave a great interest to yachting tourism. This paper's main concern will be the analysis of the strategic choice of Morocco for seaside tourism and the results of that choice, three years before the 2020 vision's deadline. In the same context, it will focus on the presentation of two territorial models of marinas: the ex-nihilo model of Saïdia Mediterrania and the urban marinacity model of Rabat Bou-Regreg. Spatial and economical approaches, as well as a field survey on a sample of visitors and yachtsmen, were used to evaluate the influences of these two marinas, the differences between their models, the typology and behavior of visitors and the effects of the marinas development on tourism and on the environment. Despite their launch, these marinas are far from seeing a real craze. The visitation of international yachts is still below expectations, while the local market does not yet seem to have the means to invest in water-based recreations. Marina Saïdia suffers from the delays that affected all sea resort projects, while the Bouregreg marina does not manage to sell its real estate and recreational model, even if its marina seems to work little by little. It seems that several readjustments remain to be made to revive the model of marinas in Morocco and especially to be able to integrate it in a controversial space.
\end{abstract}

Keywords: Yachting, tourism, Morocco, Sä̈dia Marina, Bou-Regreg

\section{Introduction}

Tourism reached important levels in recent years. International arrivals exceeded 1.235 billion in 2015 according to the latest UNWTO World Tourism Barometer (2017). In these performances, coastal and marine tourism is more relevant and attractive types involving important shares of tourists. Indeed, seaside tourism is still attractive even if tourist behavior changed in the last decades. The heliotropism of destinations like the Caribbean, the Mediterranean and Pacific-Asia is always a dream for tourists all over the world. That is why coastal tourism is subject to many innovations through new models of ecotourism, marinas, yachting and nautical niche and experiences. The situation in the rising destinations is a bit different as they are far from the major tourists' flows. In

\footnotetext{
* Professor-researcher, Le laboratoire de recherche des Sciences Appliquées, A l'Environnement et au Développement Durable (SAEDD), Cadi Ayyad University Marrakech, Morocco, Ecole Supérieur de Technologie d'Essaouira, Essaouira Al Jadida - Route d'Agadir, Essaouira.
} 
terms of development, they adopt models following the recommendations of international funding organizations, promoters and hotel chains.

Moroccan tourism was designed as a social and economic development driver. Since the early 1970s, coastal tourism fascinated policy makers and inspired them to build a competitive destination even if the kingdom's most attractive product remains cultural tourism. The recent tourism strategies (Vision 2010 and 2020) and the ports strategy 2030 draw an interesting orientation to develop nautical and yachting tourism. Newly designed marinas replace the little harbors and commercial/fishing ports for pleasure boats stopovers offering a wide range of services and facilities. The 2010 and 2020 strategies were built according to a proactive policy: Le Plan Azur was articulated on big resorts and marinas involving international promoters and developers. Correspondingly, Morocco wants to take chances based on different advantages offered by its situation near Europe, its wide coast $(3,500 \mathrm{~km})$ and the crowded and expensive European marinas nearby (Canaries and Costa del Sol marinas, the French and Italian Riviera and the Adriatic).

Morocco has also embarked on a policy of marinas to promote yachting tourism, an orientation that marks a turning point in its tourism policy. Several projects have emerged, with the aim of reshaping the marine infrastructure of the kingdom. The first major projects launched were those of Marina de Bouregreg and Saïdia Mediterrania. Both projects were launched in different contexts and obey different logic systems, which deserve a thorough reflection within the subject of this study.

In this paper, the study attempt to shed light on the spatial and qualitative aspects through a comparative approach of two marinas. On one hand, the Saïdia Mediterrania is a turnkey destination created ex-nihilo based on an integrated resort where hotels, residential areas, and shopping areas are mainly oriented to international tourism. On the other hand, Bou-Regreg marina is a marina on the north side of the estuary of the river of the same name. This is a marina city model, in the most important metropolis of the country comprising two cities (Rabat and Salé) with a rich heritage dating to the 20th century (Monqid 2009). This marina project is not specifically oriented to tourism, but rather to the modernization of the image of the Capital (Mouloudi 2015). The study will be an opportunity to focus on the specificities of each marina, by studying, first, the context of their design, the territories that hosted them and then to assess their functions after launching, the typology of their customers and the constraints related to their development.

\section{Literature Review}

Nautical tourism is a tourism niche that combines the whole of marine recreation activities in destination shores and ports by offering facilities and services for dry land tourists, cruisers and yachtsmen. In other words, all the on shore and off shore involving activities (Kasum et al. 2011, Lam Gonzales et al. 2015b), comprising floating, submarine and land infrastructure (Lukovic 
2007) with a strong marine component as defined by Lukovic, (Lukovic \& Kizielewicz 2013). The importance of such a niche is that it is not only limited to the marine factors and equipment, but also involves the cultural conditions, land facilities and environment in the hosting marinas and lands. Indeed, it is one of the most complex niches, implicating several actors and institutions in the process of production and consumption. According to this point of view, many studies show its important economic and social potentials and wish for a tourist market with significant purchasing power (Lam Gonzales et al. 2015b). The models of marinas in the French Riviera, Spanish Riviera and the Caribbean are significant in defending that point of view.

Sea and water are important ingredients for seaside tourism (BahraouiBuret et al. 1983, Aguiló et al. 2005). Certainly, seaside tourism receives the highest tourist flows over the world. "Coastal and maritime tourism has become one of the main areas of growth of Tourism" (FEDETON 2012). For that reason, nautical tourism was subject of an important number of studies. The major ones focus on the Caribbean (Lett 1983, Caumont 2005). Other studies were applied to the Mediterranean ${ }^{1}$ with primary emphasis on the eastern destinations and the Adriatic (especially Croatia) and sometimes comparatives approaches between different destinations (Favro \& Glamuzina 2005, Favro \& Saganić 2006, Hall 2003, Rutin 2010). Rutin concluded the differences of the growth models of coastal tourism of Tunisia and Croatia. He presented Tunisia as a destination of continuity and stability compared to Croatia, where coastal tourism suffers from a seasonality effect due to climate conditions.

In their book about a dynamic and multidimensional analysis approach of the marinas in France, Bétournée and Valcke (2015) revealed the role of marinas in territorial restructuring and renewal processes. In this process social, economic, and cultural particularities of the hosting lands must be integrated with the conception of the marinas (Dehoorne 2007, Retière 2003, Rieucau 2000) to build a strong brand (image) in a context of harsh competitiveness. Bernard $(1999,2000)$ established the importance of the marinas in France for the coastal areas after decades of the interesting thesis of Vieville (1972) about the demand on marinas in La Côte d'Azur. In his geographical analysis of the marinas in France (Bernard 2000), he showed the transition from the parking harbor to recreational ports. The rise of environmental sensitivity since the $2000 \mathrm{~s}$ argues in favor of increasing studies oriented towards the impacts of marina development on marine and coastal environments (Jordan 2009, Hall 2003).

The maritimization of Morocco began during the French protectorate with the modernization of the Casablanca Harbor and the development of the first marinas for the French settlers. The phenomenon changed the centrality of the country's economy, which before had been concentrated in the continental

\footnotetext{
${ }^{1}$ According to the European Boating Industry "There are over 4,500 marinas in Europe, which offer 1.75 million berths for a total boat park of 6.3 million vessels. Today, $70 \%$ of boat charter takes place in Europe, with a significant part being held in the Mediterranean Sea. These activities represent an important income for coastal and insular economies with boating, water sports and marinas accounting for 180,000 jobs and generating approximately 17 billion euros in revenue per year across Europe.” (European Boating Industry, 2017)
} 
cities like Marrakech and Fes. However, studies of the role of nautical tourism in Morocco are rare and sporadic. Researchers have focused instead on issues related to commercial and industrial harbors (El Khayat 2002). Mouloudi (2015), in his pioneer and well-documented research about the urban planning of the capital, explained the importance of the international status hoped by the modernization of Rabat. Meanwhile, the existing studies of Saïdia marina focus on the environmental impacts of the integrated resorts on the local ecosystem (Salmon et al. 2010, Snoussi et al. 2008, Sbai et al. 2005, Boumeaza et al. 2010). Their works exposed many side effects of construction and infrastructure works.

The only studies about the marinas and nautical tourism in Morocco were conducted by Lam Gonzales et al (2015a; 2015b). In their two studies, they exposed the disparities between the Canary Islands and Agadir Marina as yachting destinations. Hillali (2005), years before in his analysis of the social and geographical aspects of coastal tourism in Morocco, presented the first projects of marina Restinga Smir and Kabila in the Mediterranean, and pointed to their weak impact. Berriane $(1992,2002)$ talked also about marinas as a new niche through the new projects of the millennium (Vellas \& Mehadji 2005) despite the geographical constraints and big competitiveness of the Spanish ones (Berriane 2002). Boujrouf (2005) gave the first spatial analysis of the projects of Vision 2010. His study exposed the participatory and territorial approaches adopted during the strategy conception (Boujrouf 2005).

\section{Methodology}

This study is conducted through two case studies: Bou-Regreg and Sïadia Mediterrania marina. It combines spatial, geographical and historical analysis based on a deductive methodology combined with a field study of a compounded sample from the marinas' visitors and yachtsmen. The first approach uses a review of studies and reports related to the marinas and the urban plans of Rabat and Saïdia Mediterrania resort; while the second evaluates the demand (typology of the tourists' flows, their behavior and perception) and the offer of the studied marinas. The field study was conducted using different questionnaires covering a sample of 30 yachtsmen and 100 visitors and tourists in each marina. The types of questionnaires were decided after two tests that revealed three important visitors profiles: day-visitors, tourists and yachtsmen. The study was conducted during the high seasons in Saïdia (from July to September 2016) and in Rabat (from September to November 2016). The choice of interviewees was random for the case of visitors and tourists met in the different places of the marinas (coffee-shops, restaurants, benches...). For the yachtsmen, the adopted procedure was to question people who had moored in the ports during the survey period.

The choice of the two marinas was dictated by the fact that they are the only marinas respecting the international standards. Both of them received the 
label Sail the World (STW $)^{2}$. This choice was made also on the basis of Sea Seek $^{3}$ (Sea Seek, 2016). Every year, this organization publishes a booklet for sailors. Similarly, the orientation towards these two case studies is also dictated by two other criteria:

- The port of Bou-Regreg is the only river city-marina in Morocco.

- Saïdia Mediterrania is the biggest turnkey station created ex-nihilo in a region far from the international tourism routes.

\section{Finding, Results and Discussion}

During past centuries, Morocco was turned essentially to the mainland leaving the coasts behind. Only the ancient foreign powers (Phoenicians, Vikings, Romans, etc.) and lately the Portuguese established some maritime counters (Lixus, Mogador and Mazagan). Ports such as Agadir, Salé, Larache and Tetouan experienced a certain commercial dynamic, while the first founded fleets obeyed for protection and defensive reasons. Bou-Regreg port maintained trade relations with cities like Venice, and its privateers caused terror in the Atlantic Ocean (Wansbrough 1962). It was not until the $18^{\text {th }}$ century that Sultan Sidi Mohamed Ben Abdellah (1757-1790) initiated the first maritime policy and founded the port of Essaouira in 1760 (Nachoui 2016). The isolation policy of Sultan Mly Slimane (1792-1822) once again closed the country. However, the pressure of the foreign European powers triggered the process of maritimization under Sultan Mly Abderrahmane Bnou Hicham (1822-1859), involving the ports of Tangier, Tetouan, El Jadida, Safi, Casablanca and Larache (Nachoui 2016). Since 1912, the port of Casablanca gradually has become the most important one, especially under the protectorate regime (Célérier 1934).

Correspondingly, the practice of nautical tourism is closely linked to colonization. Beaches, close to the first modern urban centers, gradually formed the germs of the first nautical activities ${ }^{4}$ in Mehdia near Port Lyautey, as well

\footnotetext{
${ }^{2}$ https://dev.stw.fr/

${ }^{3}$ http://www.sea-seek.com/

${ }^{4}$ The practice of water sports in Morocco was concomitant with the installation of the colonists who initiated the first clubs and associations attached to the French federation in the Morocco administration area and Spanish in the Spanish jurisdiction. Rowing, will be the flagship activity after the creation of the first Club in the Bou-Regreg river banks in 1923. The number of Moroccans practicing yachting and rowing was restricted but gradually evolved after independence and until the 1980s. It had suffered from the departure of the French residents. Also, Tangier experienced the first arrival of yachts in the early 1900s. The same city will see in 1925, the foundation of the first nautical club "Le Royal Yacht Club de Tanger". The yachting activity will be developed step by step in the small ports that will see the organization of several regattas due to the action of the federation of the yachting in 1925. At the end of the Second World War, surfing was introduced by the Americans to the beach of Mehdia, not far from the naval base in Kenitra. The 1980s saw the development of this practice on several beaches and the appearance of several schools and clubs after a period of amateur practice. These schools will make surfing the first water sports in Morocco and will be widely democratized in the Moroccan coasts. The country will have several champions in the field and internationally renowned surf spots (Guibert, 2008).
} 
as in Fedala and Oualidia in the Atlantic coast. In the Mediterranean, Rio Martin or the current city (the actual Martil) like Hoceima or Saïdia in the Oriental region were frequented by Spanish settlers. Beach cottages, villas and hotels were built along the coast line from Tetouan to the Sebta enclave between the two wars, thus beginning the process of coastal urbanization (Jiménez \& Guerrero 2010) which continued after independence.

\section{All for a Marina in Every Coastal Moroccan City}

According to Moroccan coastal law, the linear public maritime domain is estimated to be $3,411 \mathrm{~km}(593 \mathrm{~km}$ in the Mediterranean Sea and 2,818 km in Atlantic Ocean). According to l'Agence Nationale des Ports, Morocco has a leisure port heritage composed of 6 marinas ${ }^{5}$. A tourist legacy has evolved over time, marked by major strategic failures and a timeless international conjuncture. The appeal of yachting among Moroccan decision-makers worked in the early 1960s. They dreamed of large integrated seaside stations in Tangier and Agadir like in Spain. These first resorts were not equipped with marinas and recreational facilities to receive boats and travelers. Rather, the commercial and fishing harbors served as ports of call for yachtsmen attending Morocco.

After independence, tourism was recognized as a national priority. The first development actions initiated the development of the seaside. But tourism was still in its early years of development. The earthquake of Agadir encouraged the building of the first seaside and coastal tourism destination on the Atlantic (Péré 1972). For the first time in history, the investment was turned to the Atlantic coast instead of the Mediterranean. Later in the 1970s, the importance given to tourism as a locomotive for development led decision-makers to launch the first ZAP (Zones d'Aménagement Touristiques) in Tangier and Agadir (Hillali 2005). Despite this, it takes years to acquire a National Ports Master Plan (PDPN) within the framework of the triennial plan (1978-1980). The development of port heritage was essentially focused on the creation of the new ports of Nador and Jorf Lasfar.

In the 1980s, a maritime specialization policy was adopted (Mohammedia in hydrocarbons, Jorf Asfar in phosphates) for the modernization of the port of Agadir and the construction of new ports (Beni Nssar) (Nachoui 2016). Then again, the dreams of Moroccan decision-makers were blocked by a lack of financial resources, the decline of the Moroccan private sector, and by the consequences of the gas crisis. The projects of Tangier and Tetouan regions

\footnotetext{
${ }^{5}$ The ANP list of the Moroccan port heritage includes also: 13 ports of international trade (Nador, Al Hoceima, Tangier, Tanger-Med, Kenitra, Mohammedia, Casablanca, Jorf Lasfar, Safi, Agadir, Tantan, Laayoune and Dakhla), 10 regional fishing harbors: (Ras kebdana, El Jedha, M'diq, Larache, Mehdia, El Jadida, Essaouira, Sidi Ifni, Tarfaya and Boujdour), 9 local fishing harbors: (Cala Iris, Sidi Hssaaine, Chmaala, Fnideq, Ksar Sghir, Assilah, Salé, Souiria Lakdima and Imesouane). And 7 ports de plaisance: (Saidia, Kabila, Marina Smir, Bouregreg, Sables d'or et Marina d'Agadir). (Ministère de l'équipement et des transports, 2011)
} 
ended up in the nets of real-estate speculation (second homes and villa) (Jiménez \& Guerrero 2010).

The failure of these policies before the 1990s was imminent. In fact, it was difficult for the state to be present both as a promoter and investor, and the successions of the crisis and the pressure of the IMF and World Bank through the SAP (Hillali 1985, 2005) were significant. Nevertheless, the state remained attached to seaside tourism development. Therefore, the adoption of a Marina Master Plan (Berriane 1992) including new projects (Bou-Regreg, Sidi Labed, Restinga Smir and Kabila) was the first step in the yachting tourism orientation. Only the Restinga-Smir marina (Vessel of 2,080 linear meters and 450 berths) and Kabila (498 meters), both situated on the Mediterranean coast, were inaugurated by the late 1990s (Hillali 2005).

From 2000, the new spatial planning policy boosted the maritime policy planning in international ports (Tanger Med and Nador West) and took into consideration tourism and spatial balances between the different regions. The same guidelines will be followed in the ports strategy 2030, devoting resource to make the country an international hub for marine logistics and a destination for yachting tourism. Indeed, since the 2000s, the yachting sector has been framed by two cross-cutting strategies: the Plan Azur of the tourism sector (Vision $2010^{6}$ and 2020) (Ministère du Tourisme 2011) and the maritime strategy 20307. The Plan Azur designates six new touristic resorts ${ }^{8}$ and two marinas (Saïdia in the Mediterranean and La Plage Blanche in the Atlantic Ocean). The model of development of the new stations is based on the intervention of the government to facilitate the procedures of land acquisition, encouraging rates, and the preparation of infrastructures in the hosting station ${ }^{9}$ (Vellas \& Mehadji 2005). However, the 2010 tourism vision faced many difficulties (FNT 2008). The oldest programmed station of Taghazout had to change the promoter, while other projects including Rabat and Saïdia were postponed both in Rabat. The international economic circumstances had been weighty and constraining.

\footnotetext{
${ }^{6}$ The Plan Azur is the main component of the Moroccan touristic strategy "Vision 2010" adopted in the early 2000 and aiming to reach 10 million tourists and a hotel beds capacity of 160000 beds. By 2010 The Azur plan was designed to orientate the country during the coming decade from a cultural destination to a seaside one (Vellas \& Mehadji, 2005) with a new generation of integrated resorts and stations, all ex-nihilo.

${ }^{7}$ The Maritim strategy 2030, had identified six competitive maritim poles to develop : l'Oriental, Le pôle du Nord-ouest, Le pôle Kénitra-Mohammedia-Casablanca, Le pôle de Abda-Doukkala, Le pôle du Souss-Tensif, Le pôle des ports du Sud. (Ministère de l'équipement et du Transport, 2011).

${ }^{8}$ Saïdia, Mogador, Mazagan, Lixus, Taghazout and la Plage Blanche.

${ }^{9}$ The private sector will play an important role in these new projects. Many financing mechanisms were developed and the state was engaged to facilitate possible loans, special interest rates for loans and leasing and possibilities of participation of the state in some financial agreements and business plans to ensure the take-off the Vision. Conventions had been signed by foreign promoters who had responded to the call by the State. Promoters in the tourism and real estate sectors such as FADESA for Saïdia Mediterrania and Plage Blanche, Thomas Piron, Accor and Colbert Orco for Mogador, Kerzener, CDG, SOMED and MAMDA for Mazagan, Thomas and Piron, Colbert Orco for Khemiss Sehel Lixus, Colony Capital and Dallah Al Baraka replaced by SATOCAN for Taghazout.
} 
At the end of 2016, Morocco had seven operational marinas, two under construction, and others under study (Nador, Alhuceima, and Oued Lau) ${ }^{10}$ (see Map 1). Meanwhile, the overall capacity of the functional marinas was 2836 berths; this will rise to 4867 after the completion of the works of the marinas of Casablanca and Tangier and the extension of Saïdia marinas (see Table 1).

Table 1. Marina's Capacity and Activity in Morocco

\begin{tabular}{|l|c|c|c|}
\hline & $\begin{array}{c}\text { Capacity } \\
\text { (berths) }\end{array}$ & $\begin{array}{c}\text { Operational } \\
\text { (berths) }\end{array}$ & Activity (estimated) \\
\hline Agadir & 316 & 316 & $1 / 3$ \\
\hline Casablanca & 135 & - & Under construction \\
\hline Bou-Regreg & 350 & 250 & $1 / 4$ of the capacity \\
\hline Mdieq & 100 & 100 & $235(2010)-245(2011)$ \\
\hline Saïdia & 1200 & 804 & 300 \\
\hline Tanger & 1400 & - & Under construction \\
\hline Asilah & 100 & 100 & NA \\
\hline Restinga Smir & 450 & 450 & $\begin{array}{c}\text { Average of 20 motor boats and } \\
\text { sailboats }\end{array}$ \\
\hline Kabila & 454 & 454 & 144 \\
\hline $\begin{array}{l}\text { Marchika } \\
\text { Atalyoun) }\end{array}$ & 350 & 350 & - \\
\hline Ras Kebdana & 12 & 12 & \\
\hline
\end{tabular}

Source: prepared by the author from ANP data

The ANP does not have accurate statistics about marinas and yachtsmen entries. The statistics available are sporadic, old or only estimates without any details in the months, the duration of the stopovers, and the nationalities of the yachtsmen. This data covers the period of 2010-2011, which is available for only two ports (Mdieq, Saïdia) and an estimate number for the Essaouira fishing port. In that respect, the total number of pleasure boat entries was estimated to be 676 in 2011. Saïdia registered 300 entries, while Mdieq received only 235 boats in 2010 and 245 in 2011. The estimated entries to Marchika Atalyoun, according to the ANP, was 144 boats the same year, ${ }^{11}$ while the Bou-Rereg marina's estimated activity was $1 / 3$ capacity. These sporadic statistics show the importance of Mediterranean marinas and a global low attendance, a reality explained in the analysis of the marinas of Bou-Rereg and Saïdia.

\footnotetext{
${ }^{10}$ The sites which could potentially host a Marina are Cala Charranesn Sidi Lahcen and Site 7-A, in Nador, Issly, Tala Youssef in Hoceima and Oued El Marsa, near Tanger.

${ }^{11}$ www.anp.org.ma consulted in 15.3.2017
} 
Map 1. Functional and Under Project Marinas in Morocco

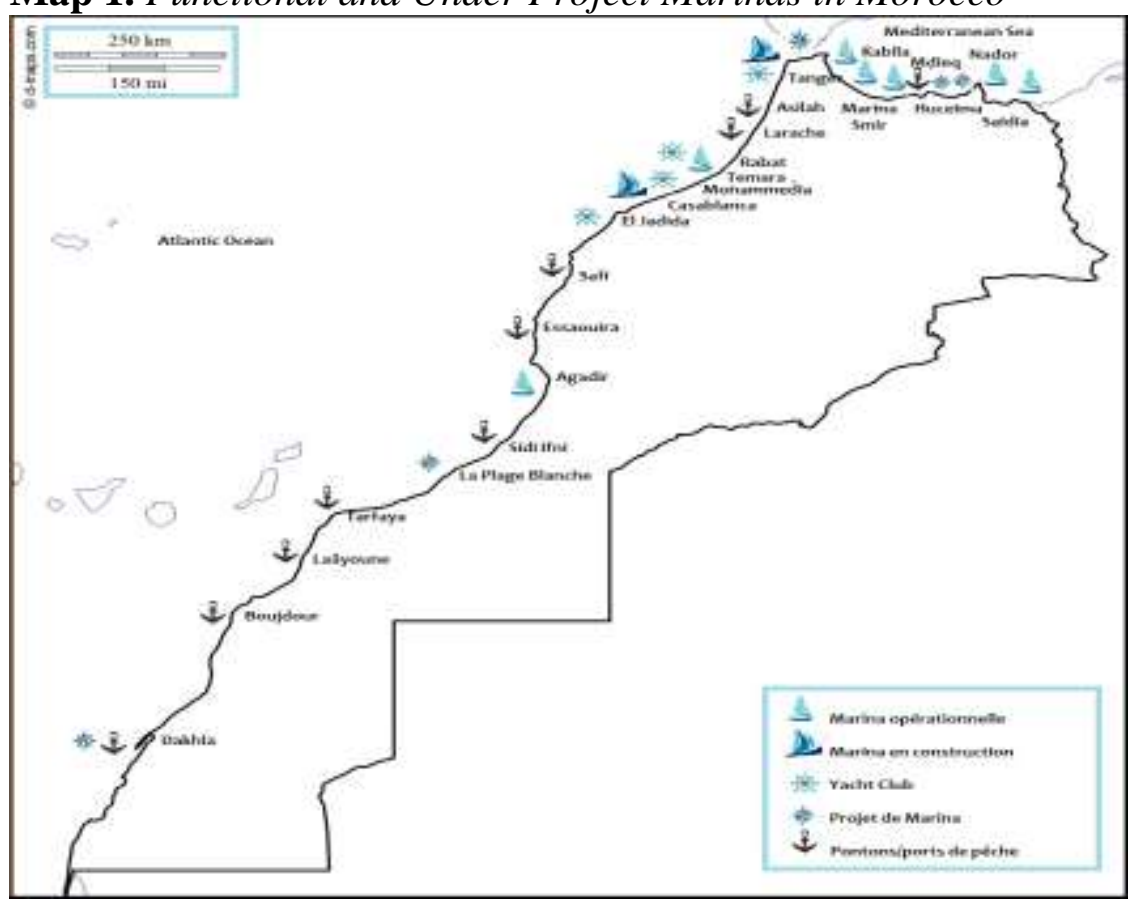

Source: conception of the author from ANP Data

\section{Comparative Analysis between two Marinas Models}

Between the $14^{\text {th }}$ and $20^{\text {th }}$ century, Salé was an active and influential international fluvial port in North Africa. The whole Bou-Regreg project offers the capital the option of re-entering the quorum of international cities using maritime potential. The city renewal will be based on aquatic potentials after decades of spatial colonial segregation.

\section{Bou-Regreg Marina, the River Marina-city Model}

An air of déjà vu glides over this project, which spent years in the libraries of the gray literature. Planned in 1989 (Berriane 1992), the Bou-Rereg marina was inaugurated in 2008 over 8.2 ha. It offers 350 berths (only 250 operational actually) to host boats of 8 to $30 \mathrm{~m}$ long with a boat draught of a maximum $4 \mathrm{~m}$ (see Figure 1). The marina's equipment is limited to a shop for boats and sailing equipment, customs, police and harbor master offices and some restaurants. 
Figure 1. Bou-Regreg Marina and the Reorganization of Rabat-Salé

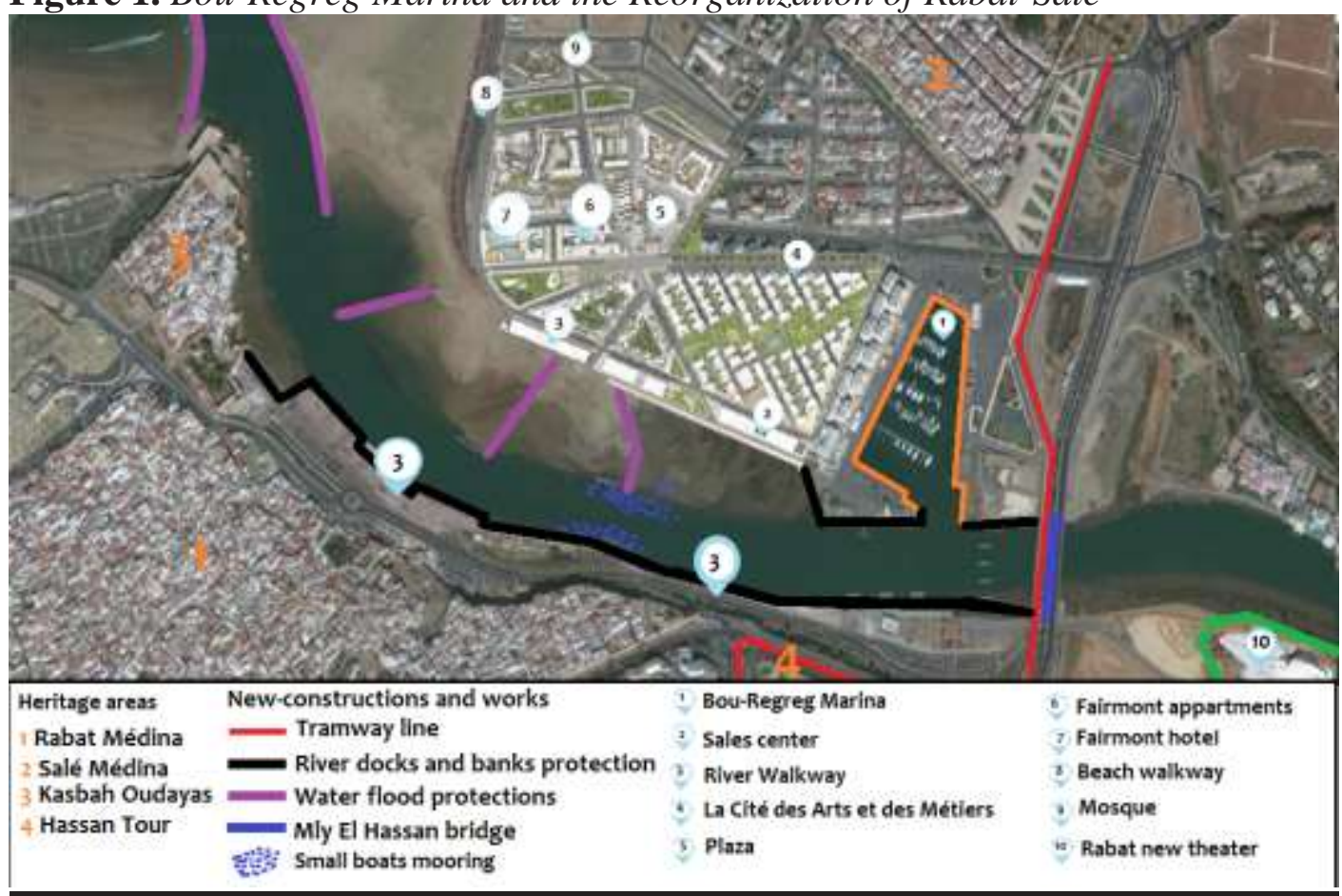

Source: conception of the author

The marina is part of the larger project for the Bou-Rereg new urban plan ${ }^{12}$ and connects with the Hassan II Bridge nearby the first finished equipments. The ambitious project uses the river (Mouloudi 2015) and the imposing building heritage (Chellah necropolis, Kasbah Oudayas, Medinas of Rabat and Salé, the city of pirates) to beautify the Rabat-Salé metropolis ${ }^{13}$. Therefore, the plan included important infrastructures and works to strengthen the connectivity of the metropolis through a Tramway and bridges and to convert some abandoned and forgotten historical buildings for use (Mouloudi 2015). The former military hospital was converted to a 5-star hotel.

The image of the capital is changing day by day. Much futurist and redesigned equipment, such as tramway, bridges, TGV train, theaters, Museums, and events (Mawazine), had been launched. In sum, the ambition of the capital (Direction de l' Urbanisme 2006) is to raise up the metropolis (Mouloudi 2015, Signoles et al 2014) to the quorum of international cities as initiated in the United States in early 1960, in Europe in the 1990s, and in some Arab capitals (Dubai, Beirut) in the 2000s.

\footnotetext{
${ }^{12}$ Rabat and Salé urban plan (SDAU, le Schéma d'Aménagement Urbain) approved in 1995 was the first urban plan to offer a vision of the future of the capital with the integration of the seaside (coastal walkway from Temara to Salé) and Bou-Regreg valley in the conception of the city. The plan includes three marinas in all that area.

${ }^{13}$ It covers the metropolitan area between Kenitra in the north and Casablanca to the south. The metropolis was shaped by the Schéma national d'aménagement du territoire (SNAT) (Direction de l'Aménagement du territoire. 2002)
} 
Without a doubt, the reorganization of the capital requires many aspects. The most important is the appropriation of the riverbanks by new elites and the wealthy social classes. Deluxe residential areas, high standing apartments, recreational facilities, and shopping centers housing international brands (Hotels, Spas, malls, clubs...) change the structure and the centrality of both cities. Expropriation and requisition of the lower social classes' lands and activities (artisanal fishing) had served this plan. At the same time, the medinas, known to house weak and poor inhabitants, are under a process of gentrification with the settling in of the upper social classes.

With more than $80 \%$ of the berths empty, the marina is totally oriented to the international market. During the fields' studies, only 35 boats are counted on the berths. The majority consisted of motorboats and the rest sailboats. Only five boats were on the dry parking. The flags clearly showed the dominance of the French boats. That seems normal, because even with high incomes, the upper Moroccan does not have much interest in buying pleasure boats.

The Moroccan society is discovering nautical leisure even with the existence of many nautical clubs. The practice and the number of the licenses are very low. Water sports and activities remain the privilege of a little elite, and take the form of schools and rental offices. The practice of water sports could be considered a sign of social differentiation. However, for the local middle class, the marina and the riversides are recreational areas. They take ownership of the river shores and the marina wharfs by walking, jogging, and sitting around on benches or in restaurants and coffee shops in the area. For the modest classes, Rabat riverside is invaded during the afternoon and the night to enjoy the fairground and some informal activities, which are not permitted in the Salé side street, such as vendors of popcorn and candies, chickpea boots and electric cars for children. In contrast, in the walkway of the marina, food trucks, cozy coffee shops and international brands furnish the landscape of the opposite shore.

Regarding tourism, the marina appears disconnected from touristic activities. In Salé, the only hotel is situated upstream of Hassan II Bridge. The city is known to not be an attractive city for tourists. It is marginalized by the domination of Rabat and the disinterest of the tour operators, despite its significant heritage (Mederssa, Medina, etc.). In reality, the path that took the urbanization of Salé transformed into a dormitory-city for the civil and military administration corps working in Rabat. The cheap land and the possible building extension to the north and the east reinforced the construction pressure. As a result, the city took the form of a concentration of houses and buildings without any interest. Though, since the achievement of the marina, the development of some riads in the Medina nearby reveals the beginning of a change in the function of the city, even if it is limited to the surrounding marina.

Unlike Salé, Rabat is an important stopover for some cultural tours. It still remains far from the intense touristic activity of Marrakech and Fes. The hotel bed capacity and the airport connections are limited ${ }^{14}$. The accommodation

\footnotetext{
${ }^{14}$ Recently Rabat-Salé airport was opened to low-cost flights. The arrivals, increased significantly from 216117 passengers to 328844 passengers between 2013 and 2014. It climbed to 330339 passengers in 2015. The year 2014 experienced a large bench in arrivals at the airport's border
} 
capacity didn't progress even with the 2010 and 2020 Visions. Restricted in its role as a simple on-route tourism town deserving only a $1 / 2$ day tour, its hotel capacity was 3861 beds in 2000 . It rose to 4957 beds in 2010 with an annual growth rate of $2.83 \%$ per year, as the best beds capacity during the whole decade. From 2010 to 2015, this rate was approximately 4\% per year. 2012 recorded $8 \%$, the best growth rate during the whole period. It stagnated in 2014 and 2015, as it did not exceed 5,842 beds. Consequently, the hotel bed capacity of Rabat is now among the weakest in Morocco ${ }^{15}$. It did not exceed $2.6 \%$ of the national hotel capacity in 2015 (Observatoire du tourisme 2016).

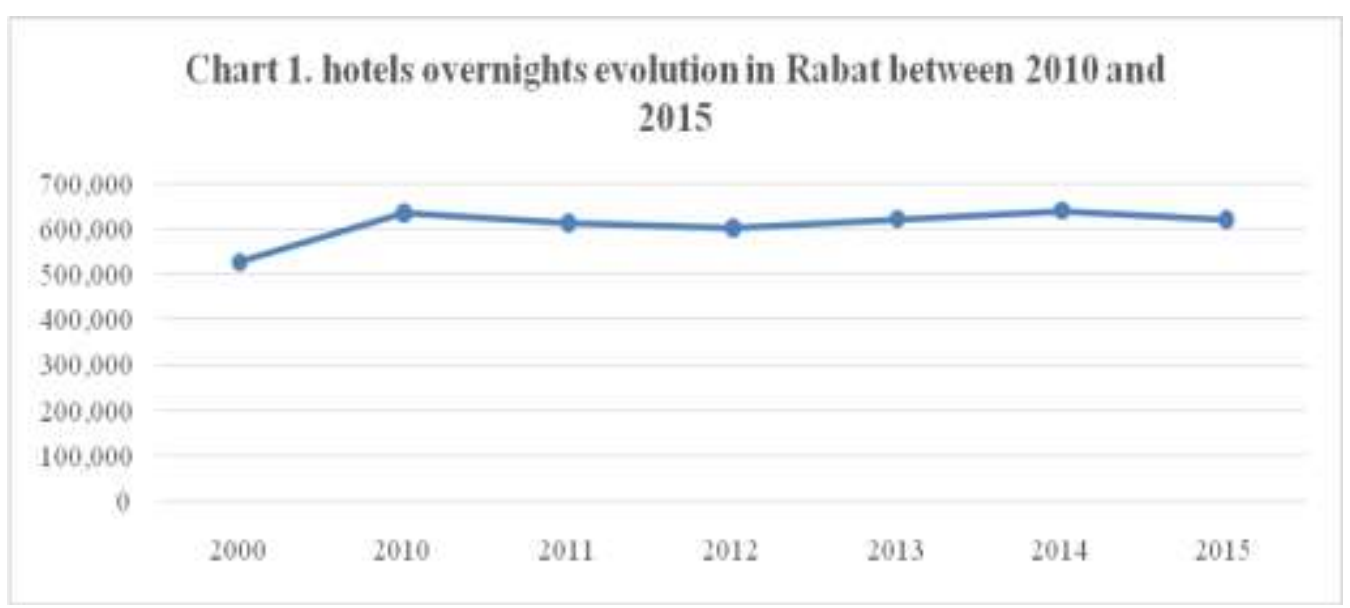

Source: Conception of the author from Observatoire du tourisme data

The analysis of hotel visits between 2000 and 2010 reveals the growth of tourists to be $2 \%$ in 10 years (from 527,374 nights to 635,329 nights) (see Chart 1). That growth was marked by its instability, and significant decline in 2011 and 2012. 2013 saw a slight rise before falling further. This turbulent evolution is explained by the international situation during the period. 2014 recorded the best numbers of overnights throughout that period (639441 overnights). It will decline of $3 \%$ in 2015 according to Observatoire du Tourisme (2016).

The hotel occupancy rate was the only excellent indicator. Accordingly, Rabat shows the best performance all over the country. The Ministry of Tourism data indicated a yearly average occupancy rate of 55\%, despite a slight decrease in 2015. During the same year, the average number of overnights differs between 66363 overnights for May as the best month and 43807 overnights for July as the lowest one.

posts with a rate of $52 \%$. The important low-cost flights from Jet air Fly then TUI Fly as well as Ryan had very limited effects on tourism. The airport arrivals in 2015 reached 330339 passengers (161785 Moroccan resident abroad and 168554 tourists) respectively $49 \%$ and $51 \%$

${ }^{15}$ In sum, 51 hotels and guest houses. The category 3 stars is the dominant one with $31 \%$ of the total capacity followed by the category $4^{*}(27 \%)$ and $5^{*}(25 \%)$. Unlike other tourist cities Rabat has more hotels of lower categories. It should not be forgotten that Rabat is an administrative and had an important dynamic in terms of business tourism. In Salé nearby, the hotel capacity according to the tourism ministry statistics is limited to 124 beds in 2 hotels. The statistics do not include the new riads and guest houses as per Rabat. 
In the years to come, the situation may change with new hotels opening, such as Fairmont and Borj Al Bahr, to fortify the bed capacity in both Rabat and Salé. The recreational functions will be enhanced by other equipment: Museums, theater, new marinas, malls and business centers, and high standing residences (Bab Al Bahr, Saphira and la Cité des Arts et Métiers). The Bou-Regreg area will be the new focal point after the saturation of Agdal and Hay Ryad districts.

In summary, the Bou-Regreg marina design aimed to reorganize the capital by bringing it back to its waters. If it mainly targets a European foreign clientele, the Rabat marina is still far from imposing itself on the tourists' level. There are still many handicaps to making it a real tourist place. The low hotel capacity of Rabat, the limited number of air connections and the Moroccan population consumption habits are still weak points. As showed, Bou-Regreg marina-city is remodeling the structure and functions of the riverbanks. This is an exceptional qualitative leap aiming to raise the capital city image at the local and international levels. The effects on nautical tourism need time to be confirmed.

\section{Saïdia Marina in an integrated Resort Model}

Saïdia Mediterrania is one of the flagship projects of the 2010 vision and the second in terms of beds capacity, after La Plage Blanche with 29,000 Beds. It is a far-reaching project targeting the creation of a turnkey resort in a rural area, though not tourist-oriented at all and without any pre-existing international touristic offer. This mammoth project covers an area of 696 ha, located $65 \mathrm{~km}$ north of Oujda and only a few kilometers west of Saïdia city. Started by the Spanish real-estate developer FADESA, it is the biggest tourist project ever carried out in Morocco. Inaugurated in 2009, it includes a marina and a nautical base inside an integrated resort of 30,000 beds capacity ( 9 hotels, 12 summer centers, 8 tourist residences, 2,700 condos, and 300 villas), an aqua park, a thalassotherapy center, a congress center, different sports facilities ( 3 golf courses, a football stadium, tennis courts, and a sport center), as well as a craft and shopping center.

Actually, of the programmed 1350 berths only 804 are functional and can receive boats from 7 to 50 meters in length $(50 \%$ of the capacity reserved to boats exceeding $12 \mathrm{~m}$ ). The marina covers a fairing area of $16,000 \mathrm{sqm}$ (to be extended to 20,000 sqm) equipped with a travel lift of 100 tons, accepting boats with draughts of 3 to $3.85 \mathrm{~m}$ (to be extended to $6 \mathrm{~m}$ in some areas), and a slipway of $10 \mathrm{~m}$ wide. The marina also offers different services and facilities: water, electricity, diesel, toilets and showers, Internet, wasted oil and rubbish collection. It also gives the possibility of dry boat storage and winterizing ${ }^{16}$. The marina is the biggest and most equipped one in Morocco.

\footnotetext{
${ }^{16}$ According to the Marina port Master, an agreement allows a stay of one year extended to 18 months per boat without interruption in the dry area or afloat.
} 
Table 2. Distribution of the Hotel Capacity in Saïdia Mediterrania Station

\begin{tabular}{|lccc|}
\hline Hotelcategory & Units & rooms & beds \\
$1^{*}$ & 3 & 65 & 115 \\
$2^{*}$ & 4 & 72 & 162 \\
$3^{*}$ & 2 & 57 & 114 \\
$5^{*}$ & 3 & 1587 & 3146 \\
Tourist residences (condos) & 2 & 246 & 1272 \\
hotels clubs & 1 & 104 & 352 \\
Total & $\mathbf{1 5}$ & $\mathbf{2 1 3 1}$ & $\mathbf{5 1 6 1}$
\end{tabular}

Source: conception of the author with data from "Le Maroc en chiffres", BMCE, 2015

In terms of hotel bed capacity, the launch allowed the region to reach 5,161 beds in 2015. The hotels' capacity was only 5,055 beds in 2013 and 5,089 beds in 2014, especially dominated by 5 stars hotels: 6 hotels of 3,146 capacity represent $61 \%$ of the total capacity followed by the tourists' residences with $24 \%$ (see Table 2). The station is clearly oriented to all-inclusive package market and vacationers.

Figure 2. Saïdia Mediterrania Resort Actual Situation

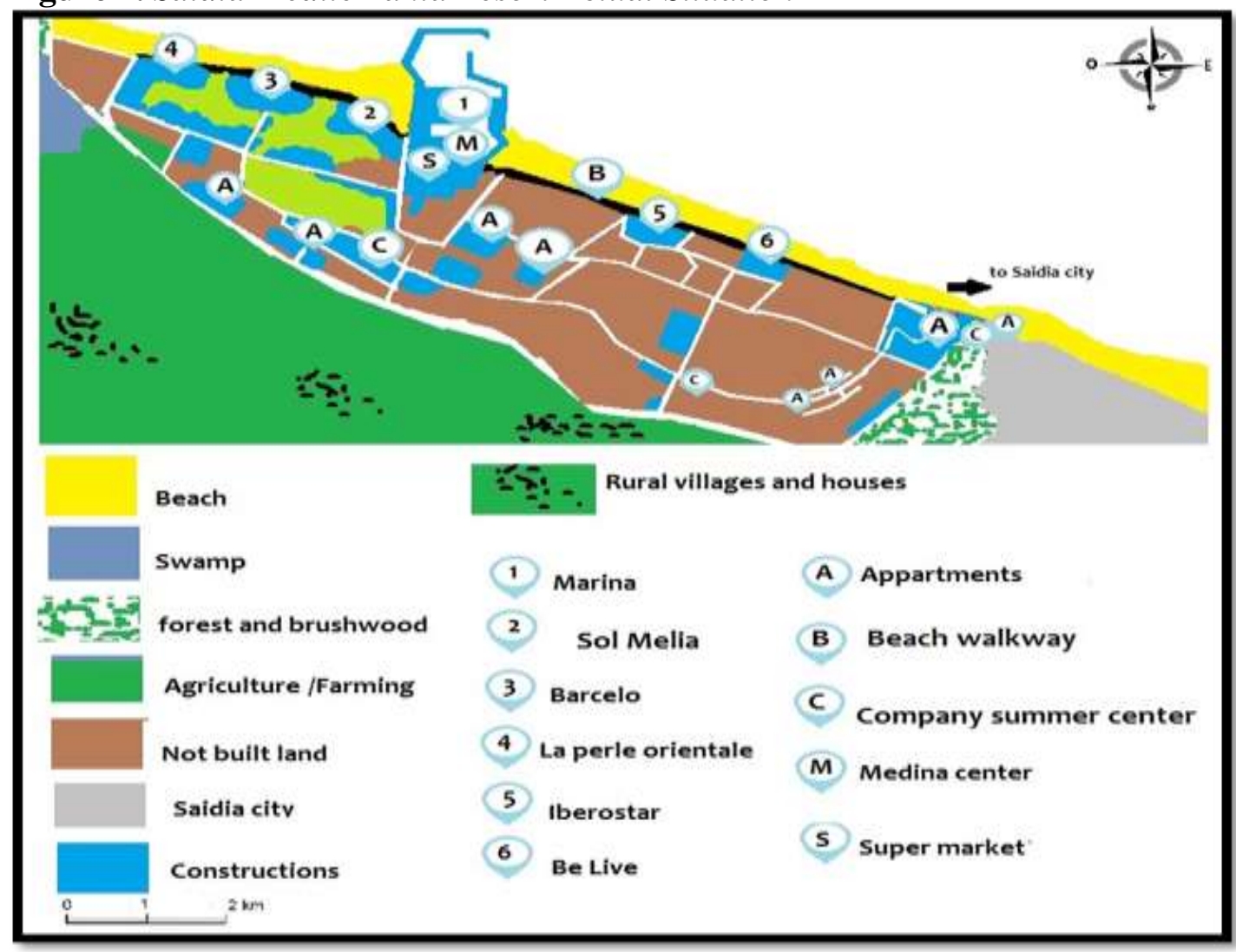

Source: Conception of the author

Contrariwise, the aftermath and the stigmas of the financial crisis of 2008 are still persistent and causing delays in the launching of many hotels and projects (see Figure 2). 
"After the bankruptcy of the Spanish group FEDESA, its Moroccan subsidiary was designed as the project developer. But, it didn't save it from the disaster scenario. The resumption of the station by the Moroccan Addoha Group, aiming to minimize the damage and helped by the state that will mobilize additional funds, wasn't efficient." $" 17$

Furthermore, the resort was deserted by international brands and tour operators. Indeed, Barcelo Saïdia closed in 3 years, and Thomas Cook cancelled many rooms' allotments during the last two years. The station has difficulties in assuring a real take-off and does not use its total potential. Nevertheless, two hotels (Sol Melia), a new tourist residence, and the aqua park opening are scheduled for this year. The marina management company had launched calls of tenders for new facilities (restaurants and coffee-shops) in the still closed premises.

The lack of tourists and especially pleasure boat statistics was also an issue of the study of Saïdia. However, the major notice is a weak level of visitors and empty docks during the high season $(2 / 3 \text { of the functional berths })^{18}$. Taking into consideration that the whole station is truly operational only within 2 to 3 months, the situation can seem dramatic. Saïdia Mediterrania suffers from a big seasonality effect. Saved by the national market, which participates in minimizing the damages, the station is still failing to impose itself as an international destination. The Algerian market could be a good option, but the land borders are still closed.

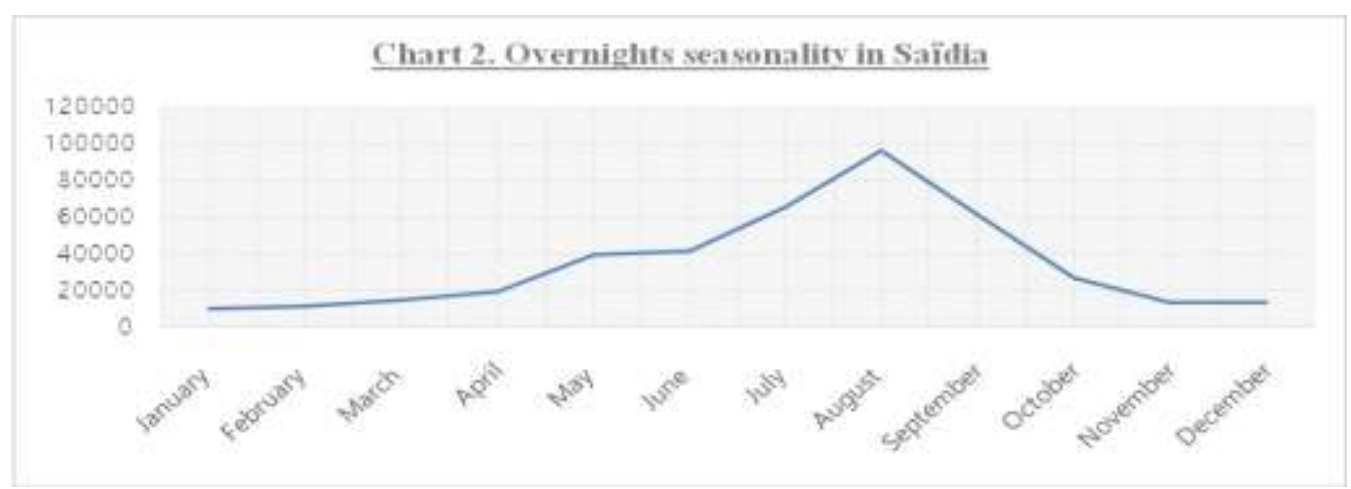

Source: Author conception from survey data

In 2015, Saïdia and the region Oujda reached 414755 overnight visits (50\% of them are largely due to the residents market compared to $48.3 \%$ in $2014^{19}$ ). In reality, the climatic conditions do not allow the region to be a major destination of seaside tourism during the winter season, compared to Agadir and the Canary Islands which are very dynamic even during winter. In the best cases, the short

\footnotetext{
${ }^{17}$ Interview with Mr M.F, Senior executive in the Moroccan ministry of tourism, 15.01.2017

${ }^{18}$ According to ANP the extimation occupation rate of the marina is $35 \%$

${ }^{19}$ Saïdia is a popular tourism destination receiving thousands of Moroccans and MRE (Moroccan resident abroad generally native of the Oriental region). It owes its achievement to the fame of the station among the population of the Eastern (proximity) reaction and for the importance of Moroccans residing abroad who spend their summer holidays there when they return to their region of origins.
} 
season covers from May until September and matches with the high season of competitive seaside destinations both for the international and national tourists.

The analysis of the tourists' statistics of the Moroccan Observatoire du Tourisme over 20 years reveals low-slung but good performances. Thus, the overnights passed from 50520 in 2000 to 356132 in 2010 (Observatoire du tourisme, 2016). The important rhythm of growth was observed in that decade with $71.01 \%$ per year. After 2010, the growth rate suffered steep falls in 2013, 2014 and 2015. The estimated yearly growth rate during this five year term did not exceed 5\%, suffering like all the Moroccan destinations from the international situation.

In 2015, the peak season recorded $64 \%$ of the total overnights (from June to September) (see Chart 2). August was the best month with $36.35 \%$ of overnight stays. But even so, the occupancy rate remains very low compared to the national rate. Saïdia Mediterrania's performance, even with all the region of Oujda-Saïdia, does not exceed 33\%. However, this is a good performance compared to 2014 (44\%) and 2013 (28\%). It reached 80\% and even 100\% during August, but it sealed by the low long season, which brought that rate down to $10 \%$ or even to $0 \%$. Indeed, the closure of some hotels is a catastrophic and bitter reality. Even worse, the village next to the marina, which is supposed to ensure a certain commercial dynamic, is still deserted. Several shops are not yet opened, while those opened are obliged to close for months or definitely (Pharmacy, grocery store, hairdresser, etc.) (Berrada 2016). The media reported several manifestations of dissatisfied merchants. They believe they have been lax and duped by the resort developer who exaggerated the station's business potential $^{20}$.

To conclude, the station is isolated like a ghetto, despite the marina and the resort developers' marketing efforts ${ }^{21}$. This model also had many difficulties to impose itself. Many interviewed people gave the description of a ghost resort in a hinterland area because of the unfinished constructions and the aloofness of such a large station from urban dynamics. Clearly, in Saïdia and even Oujda, the impact of the resort on the local economy is not significant. Transportation companies from Oujda and Berkane do work mainly in Marrakech and Fes, and the travel agencies are oriented to the local market, selling primarily Omra and Hajj programs. Even Oujda Angad and Nador Airport, for which connections were developed and reinforced, by some low-cost companies are also oriented to the Moroccan diaspora in Europe.

\footnotetext{
${ }^{20}$ Interview with a restaurant manager, august 2016

${ }^{21}$ The marina management company tries to reinforce the marketing of the nautical and yachting tourism by different events launched or sponsored during the recent years. From 2013, many events took place inside the marina like: the nautical days, the sponsorship of Saïdia Sailing cup by famous sailors and skippers (Marc Pajot), The Morocco Sailing challenge, inviting Moroccan travel influencers (bloggers) in 2016
} 


\section{Marinas Attendance, Behaviors and Satisfaction of Visitors and Sailors}

The field studies carried out reveal different profiles and types of behaviors. Three large categories can be identified: day-visitors, tourists, and yachtsmen. Day-visitors compose a large part of the interviewees as presented in the sample. The chart shows (see Chart 3) that the marinas are frequented by the residents, whereas Saïdia distinguishes the presence of a significant number of tourists compared to Bou-Regreg. Thus, $53.3 \%$ of the visitors of the day and $45.7 \%$ of tourists in Bou-Rereg, compared to $42.5 \%$ of visitors and $57.5 \%$ of tourists in Saïdia. Thus, it is obvious that the marina city model attracts more locals. Unlike Saïdia, visitors are tourists from the region during the year. During the peak season, tourists come from different cities including Rabat, Casablanca, Marrakech or Fez, or from abroad. Yachtsmen are treated separately as they are the target of the surveys and paper subject.

The quantitative and qualitative analysis of these categories, including the visitor's perception of the marinas according to their categories, could be itemized as follows.

\section{The Day-visitors}

The importance of day-visitors deserves an analysis of their profile and behavior. As they maintain a certain level of activity, the marinas far less affected by the seasonality of the tourist activity. They are the first to accept and support the marinas permanently during the year, with a peak attendance from 11 am to $18 \mathrm{pm}$ and until $1 \mathrm{am}$ during the weekends.

\section{Chart 3. Origins of the Visitors to Bou-Regreg and Saïdia Marinas}
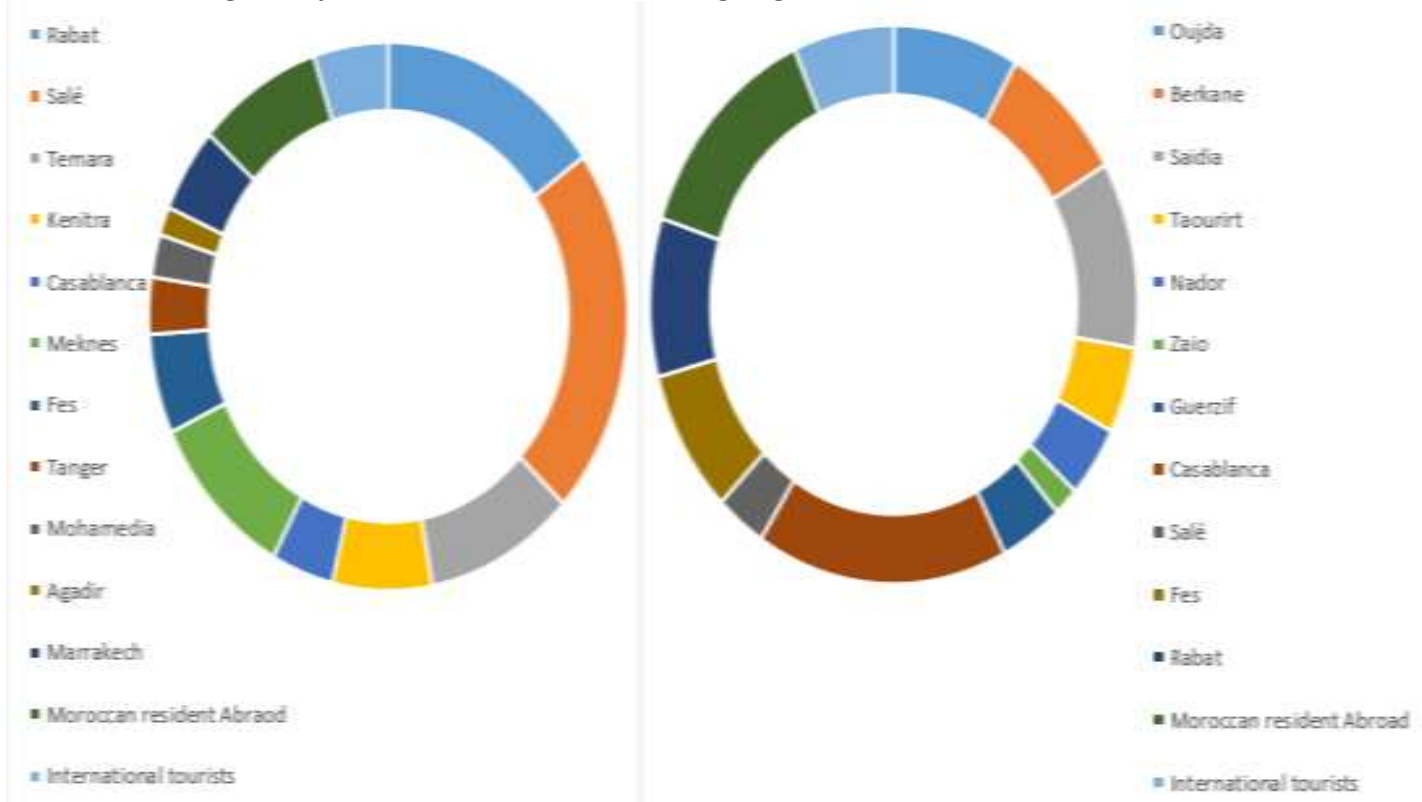

Source: Author conception from survey data 
The day visitors come in couples $(21 \%)$, groups $(25 \%)$, or families $(64 \%)$ of various ages. For Bou-Regreg marina, they are mainly the inhabitants of Salé $(33 \%)$ and mostly of the Medina next door. Generally inactive (51.2\%), they come to the river wharfs and enjoy time in the beach or boat excursions in the river mouth. In Saïdia marina, only $25.5 \%$ of the residents are from Saïdia city nearby, the others are from Oujda, Berkane, Taourirt and Nador. Both marinas attract day-visitors from a radius of $100 \mathrm{~km}$. Accessibility allows the inhabitants of these cities to come and enjoy the facilities and the modern-cozy atmosphere of these places. These day-visitors are classified into four categories:

- Ramblers/contemplators: They like to walk in the marina wharf and the riverbanks. About $48 \%$ of the local visitors, especially families of the Medina of Salé. In Saïdia they are 25.5\%.

- Coffee shop lovers: This category includes people who prefer to settle on the terraces of the coffee shops. Young people aged between 23 to 35 years old who usually come in a couple or in groups. Families or groups of friends from neighborhoods further from the marina or nearby towns. They are employed or students, including a majority in the public service in Rabat and in the private sector in Saïdia or Oujda.

- Sportsmen: Visitors of different ages. They like jogging (91\%) or cycling $(6 \%)$ in the morning and usually during weekends. They are mainly young people, mostly women reassured by security within the marina. Only $3 \%$ practice water sports (catamaran, jetski, rowing, etc.)

- Epicureans: Youth employed (72\%) and Saïdia (42\%) of the middle and upper class who appreciate experiencing different themed restaurants. In Salé, $8 \%$ prefer gastronomic restaurants. Families do also attend snacks and pizzerias in Saïdia.

\section{Tourists}

Tourists represent $46 \%$ of the people that attend Bou-Regreg marina and $57.5 \%$ of those at Saïdia. Most of them are residents (61\% for Salé and $65 \%$ for Saïdia), while the non-resident tourists (29\% in Bou-Regreg and $34 \%$ in Saïdia) in both locations are dominated by the Moroccan living abroad $(62.5 \%$ in the first and $66 \%$ in the second). During summer, both destinations are mainly attractive for national tourism.

In Bou-Regreg marina, the tourists are in general couples (10.5\%) or families $(87.2 \%)$ with two or three children. The Moroccan tourists who visit Rabat are largely visiting and living with their families or friends (97\%), while the foreign tourists, mainly French, book hotels or riads. Unlike the national tourists who stay between one week and three weeks in Rabat, the average stay of the international tourist is 2.5 days. When they are in Rabat, they all combine cultural visits, swimming in the beaches, and frequenting the marina, especially during the afternoon and the evening. 
Asked about the tourists, a restaurant manager in Bou-Rereg Marina minimized the importance of international tourists. He explained that the marina wasn't integrated with tours and said:

"This could give us the possibility to work even more and bring another type of clients. You know there are no hotels yet here. The yachtsmen who dock here rarely come. They make stopovers and they are more attracted by the medinas. Some of them go to the restaurant across the street because they have a license to serve alcoholic beverages".

In Saïdia, tourists travel mainly in families (89\%) compared to couples (8\%). In the same context, the national ones buy all-inclusive packages $(61.5 \%)$ or rent apartments in a tourist residence in Saïdia resort (21.8\%). Only $16.6 \%$ live with their families or friends. The foreign tourists also buy all inclusive packages (70.2\%) or only hotels in Saïdia or Oujda (21\%). The average stay for the national ones is 7 days for those living in hotels and 7 days to 3 weeks for those in condos or passing holidays with their families or friends. In contrast, the foreign tourist average stay varies between 2 days and one week. Saïdia is famous for being an all-inclusive and a popular destination for vacationers. The national tourists are accustomed to renting or buying second houses in Saïdia.

In general, both day-visitors and tourists appreciate the atmosphere and the freshness of the marinas during the hot days of summer. When asked about their activities, relaxing and watching boats, walking along the docks and frequenting restaurants and coffee-shops were the most mentioned activities (see Chart 4). Foreign tourists and national ones in condos visited the cities nearby, but only the foreign tourists go further to see Fes, Marrakech or further afield to the desert.

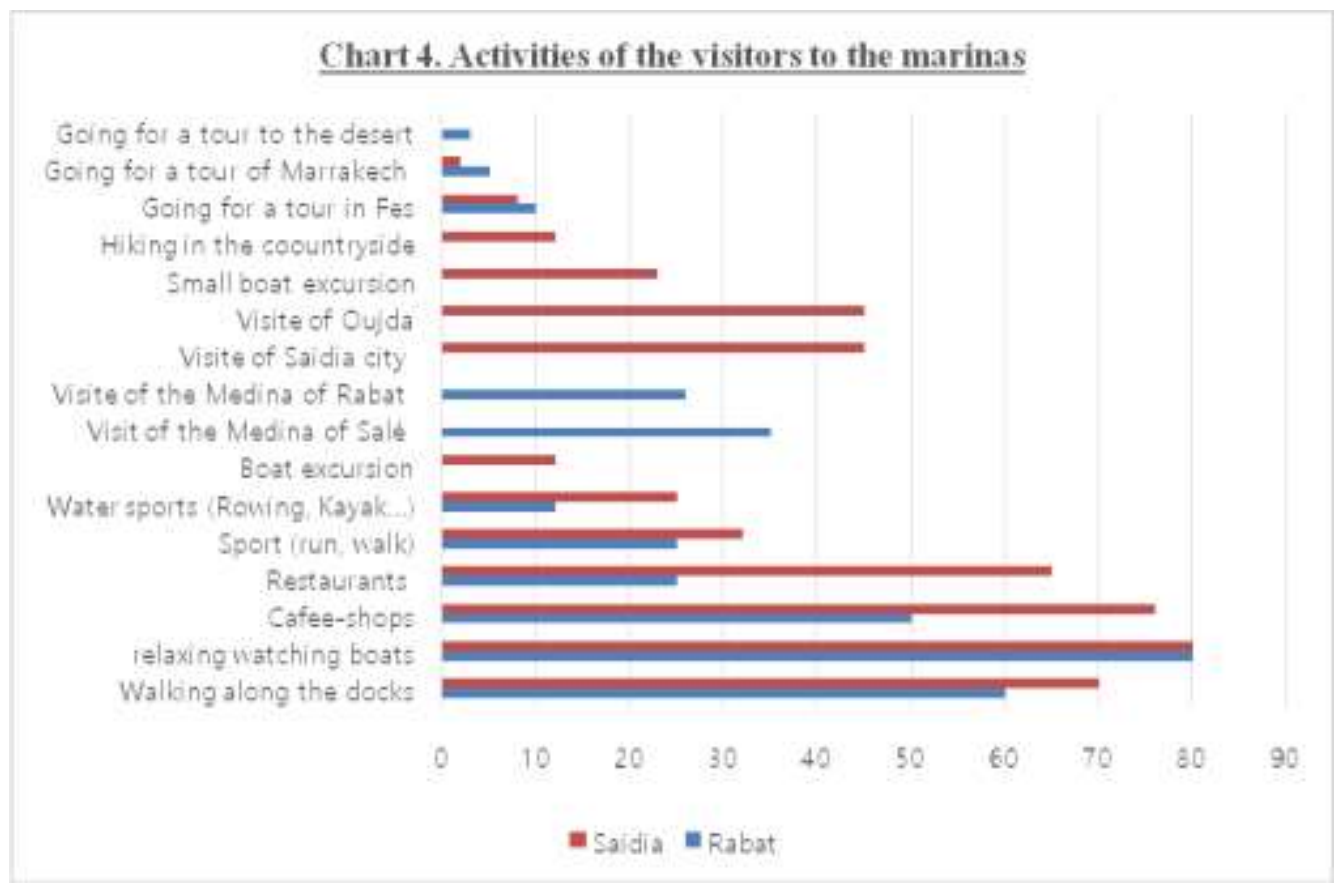

Source: Author conception from survey data 
In general, day-visitors and tourists seem to enjoy the two marinas and the services onsite. They are unanimous in their assessment of the quality and the whole environment. Yet, some people expressed a few grievances related to the social mix in Bou-Regreg and the expensive prices of restaurants or the lack of activities. Some comments received were:

- "The prices are expensive. I come here sometimes with my family and children to walk and feel a little fresh air. We are proud of the Marina. Before, we came but everything changed. We live in Bab Mrissa. It's beautiful what has been done..." A lady with her children sitting on a bench in Bou-Regreg marina

- "People come from poor neighborhoods, they behave uncivil. Since the marina is open to anyone, we are sometimes embarrassed. Yet it is a secured place but it loses a bit the luxury for which we come. I cannot even imagine what fill people who are living here all the time. All this din and hassle. It's just horrible." A young lady in the cozy restaurant of BouRegreg

- "It's a matter of culture, you know. Moroccans are not interested in water sports. There is no real clientele in Morocco for these sports... rich people bring their children to school during the weekends. You will find especially more young people who practice surf, jetski or motorboat than sailing."'Member of the Royal Nautical Club near Bou-Regreg Marina

\section{Yachtsmen}

The analysis of the structure of the moorings in the studied marinas reveals some differences. By volume, Saïdia Marina is more important and much more used for winterizing. During the investigation, the average of the occupied berths is $30 \%$ to $40 \%$ at Saïdia compared to $25 \%$ to $30 \%$ at Bou-Regreg. Another difference is the strong presence of sailboats in the first marina compared to motorboats and yachts in the second one, of which $1 / 3$ are owned by Moroccans. The marinas seem to be in a start-up phase and still have to multiply their efforts to attract other yachtsmen.

Both marinas receive mainly French flags, $89.4 \%$ in Bou-Regreg and $72 \%$ in Saïdia, as well as Spanish, 10.6\% in Bou-Regreg and 28\% in Saïdia. Yachtsmen are mostly male (72\%) aged between 49 and 56 years, residents in coastal cities (98\%), and sailing in families without children (79\%). They mostly work in the private sector, the liberal professions or have their own business. $68 \%$ of them have sailed since childhood (68\%) and navigate regularly throughout the year. They also have in common the particularity of owning their boats $(82 \%)$, compared to $18 \%$ who chartered.

The duration of their stays in Morocco fluctuates between 5 days and 15 days for those interviewed in Rabat. Those in Saïdia continue up to 20 days. Some of them take advantage of their stopover in Bou-Regreg to travel inside the country, by visiting Fez (12\%), Marrakech (5\%), or even Merzouga in the south $(1.5 \%)$. They spend less money in Bou-Regreg than in Saïdia (16 euros 
per person per day for the first and 25 euros for the second) and prefer activities like (swimming, rowing, surfing, etc.) (98\%), urban tours $(86.5 \%)$, and hiking (46.5\%), as opposed to staying in marinas.

In general, yachtsmen appreciate the whole atmosphere and the nature: beaches and mountains near Saïdia, the history and heritage of Rabat and Salé, and especially the welcome and hospitality in Morocco from the helpful and sympathetic people (see Chart 5). One of our respondents answered in these words: "We have been sailing for some time in Morocco, we made several ports with always a great welcome. We had a very good welcome in Saïdia, like in Rabat. We plan to go further south to Essaouira and Dakhla. People are kind and above all we can negotiate the prices, " and he bursts out laughing. Another French couple told us: "We loved all our stopovers, Rabat and its sympathetic souks as well as Salé, more authentic. Rabat is a peaceful town. We were able to visit all the monuments using the tramway. Overall it is a great place and the view of the Mausoleum in the evening... Que du bonheur!"

In sum, both marinas got good marks for the environment and general atmosphere. Yachtsmen appreciate the modernization of the city and the valuation of the river, the nightlife, and the lighting of the marina and vessels. They were also satisfied with the services in Bou-Rereg marina, including equipment, security, and especially the harbormaster. Likewise, they mentioned the difficulties of maneuvering boats because of swells ${ }^{22}$ and the important activity in the mouth of the river (surfers and small boats). Similarly, Saïdia seems to be "comfortable, and very secure. Customs were strict and quick and the staff professional," according to a Spanish yachtsman. Additionally, the harbor master was esteemed by all the interviewed sailors.

Many yachtsmen, who had visited Saïdia many times, felt the change in quality of the equipment and services. A yachtsman told us:

"In the time we came, Saïdia was such a desert village there were many constructions, the marina not finished and no yacht company. Now there are two international brands with experienced stuff and shops offering yacht supplies. They offer many services like cleaning, painting, anti-fouling and hull works. I talked to them they are Spanish and certified Volvo penta."

Regarding the equipment, the yachtsmen do not mention commercial facilities, shops, or banks in Bou-Regreg. "You can find a grocery store just near the marina. If you take the tramway you can goto the supermarkets Marjane or Carrefour. I noticed a pharmacy next to the marina..." In contrast, commercial services seem to be an important concern in Saïdia. Indeed, all the yachtsmen remarked about the aid station near the marina, the bank with ATM and the supermarket. They were dubious about prices, the availability of some products and the size of the supermarket.

Rates and prices are key factors in the choice for mooring ports. All the yachtsmen confirmed that they first asked for rates and compare with friends or other yachtsmen in chatting forums or social media. Thus, many sailors told as

\footnotetext{
${ }^{22}$ A similar observation, was reported by a yachtsman who came twice to Saïdia: "for those who come here during wind period "may", they could find the entry to the marina difficult because of the wave's size".
} 
that they rather prefer marinas of the Spanish enclaves Sebta (Ceuta) and Melilla: "We find berths at better prices and rip-off gas with all the facilities nearby. I also took a flight from the airport of Melilla to Madrid". The enclaves seem to be interesting for $87 \%$ of the navigators for refueling and repairing their boats. In Saïdia, another sailor told us that: "The first time I came, the rates were not clear and expensive. That's why I went to Mellilia and after to Sebta. I passed two days in Marina Smir. It was crowded of Moroccan wealthy" The Mediterranean Moroccan ports seem to have already been experienced by other persons of the sample. $55 \%$ of them had a stopover in marina Smir from which $15.5 \%$ visited Tangier, Tetouan and Chaouen. Clearly, the yachtsmen search for experiences onshore as well as better berth prices.

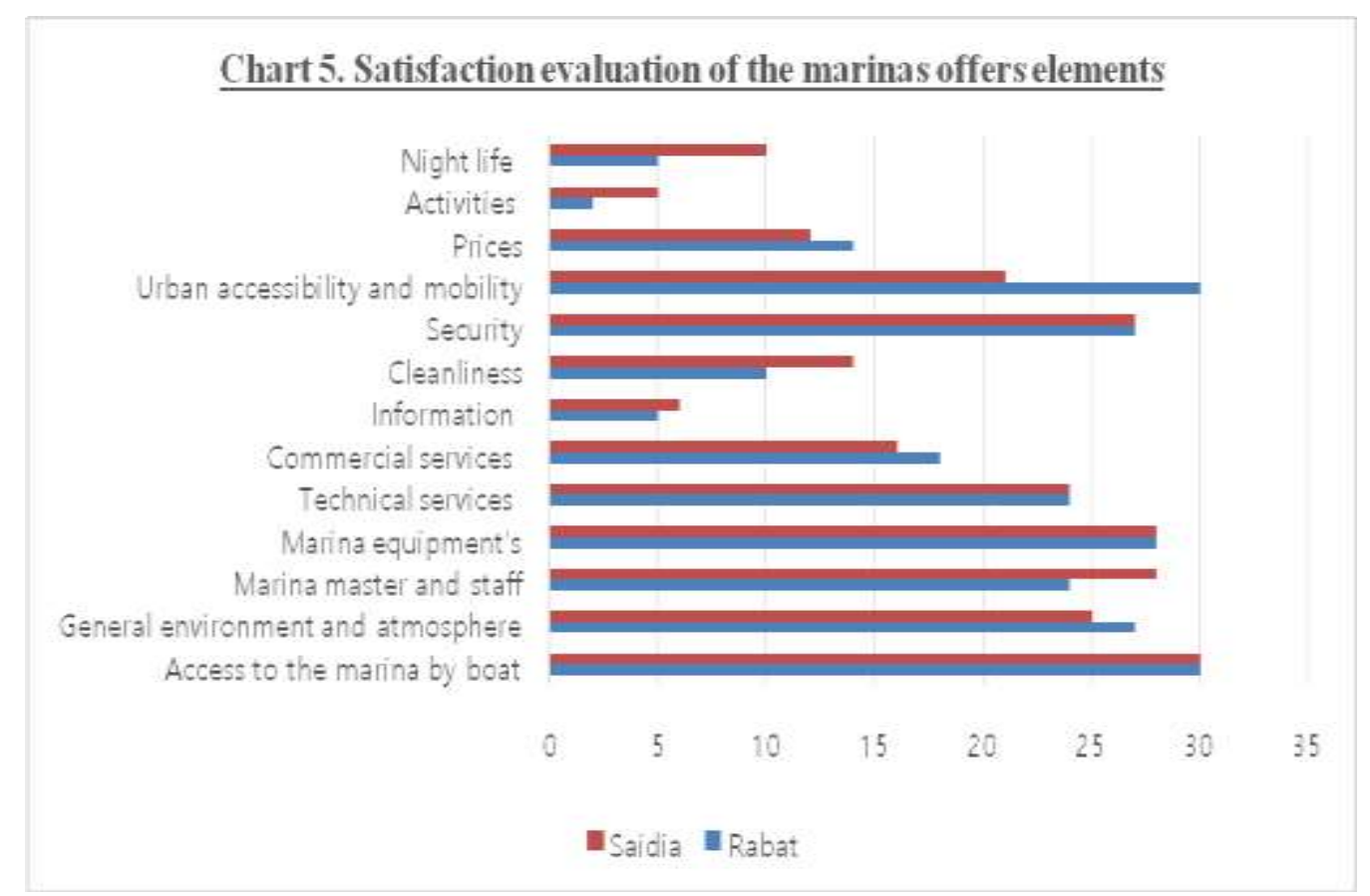

Source: Author conception from survey data

Apart from the competition between Saïdia and the Spanish enclaves, there is another competition between the Moroccan marinas revealed by the questioned sailors. The port of Marchika (Atalyoun) near Nador offers berths for winterizing with water and electricity, all for free... it gives a good anchorage alternative near Melilla and Nador, two cities well equipped with supermarkets, Spanish products, and bars. Likewise, the competition in the Mediterranean marinas is substantial. With four marinas, the competition will be harsh after the opening of Tangier Marina and the other marinas projects in Nador and Huceima.

The competition between the marinas and the fishing ports is another key factor in the navigator's choices. For example, the prices of winterizing in Mdieq (fishing port) near Marina Smir influence the frequency of vists to that port. "I got for my boat, a berth in Mdieq at half the price of Marina Smir, which is made for rich Moroccans," explained a French yachtsman. In the same context in the Atlantic coast, ports like Sable d'Or, which are not very frequented, and 
especially, Mohemmadia or Essaouira offer cheaper berths than Bou-Rereg. However, the sailors are aware that these fishing ports are dirty and crowded with aged fishing boats. They do not offer water, electricity, or sanitary facilities, etc. They can buy a stopover but not a service, revealing the need for developing services with affordable prices in both marinas.

When questioned about the grievances they could make regarding marinas, the interlocutors pointed out several topics related to both information on marinas and activities, such as tariffs as well as equipment. In Bou-Regreg, the interviewed yachtsmen were critical regarding the quality, the hygiene and food safety. They complained about the high prices and the lack of restaurants or shopping. They rather prefer to go shopping in Rabat. Another negative point is the cleanliness of the marina and especially of the showers and toilets. They seem to be neglected and left many hours without cleaning.

Other elements related to the lack of updated information about the marinas and their access caused inconvenience to yachtsmen. They cited also that the conditions of winterizing are not clear and found the number of documents requested exaggerated. For some of them, the duration of the check-in (passports) in the marina seems to be exhausting. They were even surprised that, in the logic of the Moroccan authorities, any boat is suspected.

In sum, the new marinas are attractive and had improved many elements of their offer. The differences of the two models, marina city and resort marina, give them particularities both in terms of offer. The demand is effective and could be increased for yachtsmen seeking berths available in such an exotic and interesting country. To attract them, managers need to double their efforts in terms of marketing, information, and services quality.

An effort has to be done in terms of adapting the offer to an experienceseeking clientele interested in culture, nature and experiences. The historical environment, the cultural heritage of cities such as Rabat and Salé, as well as the hinterland of Saïdia must be integrated into the offers. In the same context, technical services (maintenance, repair, sale of equipment, etc.) must be made easier since they are strongly conditioning nautical and yachting tourism demand. The question of competition between the marinas and the fishing ports should also be resolved in order to allow a real take-off of both marinas.

\section{Conclusion}

Nautical and yachting tourism is a potential niche for development driven by the beautiful and rich coastline and still growing market in Europe. In this study, two different marina models were presented (Bou-Regreg and Saïdia). Despite their differences, they express new orientations through maritimization and regionalization of coastal and yachting tourism in Morocco. The various projects of marinas that are still under construction or in the study stage will contribute to reinforcing the image of a country increasingly hooked to its coasts.

The yachtsmen are still few and show their interest for both marinas, which have seen their level of services and equipment evolved in recent years. The 
difficulty in navigating near the Moroccan coasts is a structural obstacle for navigators, but their perception of the equipment was positive. On the other hand, several points were subject to grievances: lack of navigation information, rates, hygiene, quality and activities. These elements should be taken into consideration by stockholders. As far as the behavior of people who frequent the marinas is concerned, it was possible to identify different types and profiles of visitors. Their behavior is heterogeneous, but they have in common the appreciation of the new marinas and their facilities even with the limited interest of the residents in nautical products. The study showed that the day-visitors and the national market play a decisive role in the tourism dynamics even with vacationer behavior and high seasonality.

However, the marina models studied raise many questions about environmental threats; for instance, coastal fragility, coastal line decline, and the change of local ecosystems have been investigated by many other researchers. A model of environmental management becomes a great necessity. The current situation of the coasts and the management methods lacks in terms of environment care. This one could be taken into consideration for the innovation in Moroccan nautical tourism and the marketing of the whole destination.

\section{References}

Aguiló E, Alegre J, Sard M (2005) The persistence of the sun and sand tourism model. Tourism Management 26(2): 219-231.

Bahraoui-Buret J, Bargach MN, Kaddour LM (1983) Le gisement solaire marocain. Rabat : Société Marocaine des Éditeurs Réunis, (SMER).

Bernard N (2000) Les ports de plaisance, équipements structurants de l'espace littoral. Paris: L'Harmattan.

Bernard N (1999) Du port-parking au produit touristique: l'évolution des ports de plaisance en France. Norois 182(2): 275-285.

Berrada M (2016) En échec depuis des années, la station balnéaire de Saïdia peine toujours à séduire les vacancier. Retrieved from https://ledesk.ma/2016/08/17/enechec-depuis-des-annees-la-station-balneaire-de-Saïdia-peine-toujours-a-seduireles-vacanciers/ [Accessed 1 February 2017].

Berriane M (2002) Les nouvelles tendances du développement du tourisme au Maroc. Actes du FIG 2002, Religion et Géographie. Retrieved from http://archives-fig-stdie.cndp.fr/actes/actes_2002/berriane/article.htm.

Berriane M (1992) Tourisme national et migrations de loisirs au Maroc, étude géographique. Thèse de doctorat, Série Thèse et Mémoires, $\mathrm{n}^{\circ} 16$. Faculté des Lettres et des Sciences Humaines, Rabat.

Bétournée N, Valcke S (2015) Les ports de plaisance en France, Une approche dynamique et multidimensionnelle. Editions L'Harmattan.

Boujrouf S (2005) Tourisme et aménagement du territoire au Maroc: quels agencements? Téoros 24(1). Retrieved from http://teoros.revues.org/1490.

Boumeaza T, Sbai A, Salmon M, Benata M, Ozer A (2010) Impacts écologiques des aménagements touristiques sur le littoral de Saïdia, Maroc oriental. Méditerranée. Retrieved from http://mediterranee.revues.org/4888.

Caumont H (2005) L'avenir économique du Nautisme de la Caraïbe. Mém. DESS. UFR des Sciences juridiques et économiques de la Guadeloupe- UAG. 
Célérier J (1934) Les ports de la zone française du Maroc. Annales de Géographie 43(242): 163-170. Retrieved from http://www.persee.fr/issue/geo_0003-4010_19 34_num_43_242.

Jiménez EA, Guerrero JEC (2010) Tourisme, territoire et environnement sur la côte méditerranéenne du Maroc. Cahiers de la Méditerranée 81. Retrieved from http:// cdlm.revues.org/5660.

Dehoorne O (2007) La Baie du Marin (Martinique): l'organisation d'un nouvel espace touristique autour de la plaisance. Études Caribéennes. DOI: 10.4000/etudesca ribeennes.381.

Direction de l'Aménagement du territoire (2002) Le Schéma national d'aménagement $\mathrm{du}$ territoire. Ministère de l'aménagement du territoire, de l'Eau et de l'Environnement.

Hall D (2003) Rejuvenation, Diversification and Imagery: Sustainability Conflicts for Tourism Policy in the Eastern Adriatic. Journal of Sustainable Tourism 11(2-3): 280-294.

Direction de L'urbanisme (2006) Project urbain pour la ville de Rabat: Rabat la Victorieuse. Ministère de l'Urbanisme et de l'Aménagement de l'Espace.

El Khayat M (2002) Enjeux logistiques et compétitivité du port de Casablanca. Méditerranée, tome 98. Systèmes de transport en mutation dans l'espace euroméditerranéen. En hommage au professeur Maurice Wolkowitsch, 105-112.

European Boating Industy. Retrieved from http://www.europeanboatingindustry.eu/ eu-affairs/tourism [Accessed 5 January 2017].

FEDETON (2012) European Manifest for sustainable Nautical Tourism. Brussels.

Favro S, Glamuzina N (2005) Contemporary problems of Nautical Tourism Development. Croatia, Promet, Portorož, Trieste, Zagreb, Žilina br. 107-112.

Favro S, Saganić I (2006) Sustainable development of nautical tourism in Croatia. New perspectives and values in World tourism \& tourism management in the future", TurkKazakh International Tourism Conference, (Alanya, Turkey, 2006). Book 1: 602-620.

Guibert C (2008) Le surf au Maroc. Les déterminants d'une ressource politique incertaine. Sciences Sociales et Sport 1: 115-146.

FNT (2008) Bilan stratégique de la Vision 2010. Fédération Nationale du Tourisme et DaifConseil Cabinet.

Hillali M (2005) Aspects sociogéographiques du développement du tourisme balnéaire au Maroc. Téoros 24(1): 6-11.

Hillali M (1985) Le développement du tourisme sur la côte méditerranéenne du Maroc: potentiel et action gouvernementale. Thèse de troisième cycle en urbanisme, Aix-en-Provence: Université d'Aix-Marseille III. IAR.

Jordan P (2009) Restructuring Croatia's Coastal Resorts: Change, Sustainable Development and the Incorporation of Rural Hinterlands. Journal of Sustainable Tourism 8(6) Sustainable Tourism in Post-Socialist Transformation: 525-539. DOI= http://dx.doi.org/10.1080/09669580008667384.

Lett James W Jr. (1983) Ludic and limuloid aspects of charter yacht tourism in the Caribbean. Annals of Tourism Research 10(1): 35-56.

Kasum J, Mikulicic JZ, Fredotovic B (2011) Nautical tourism. WIT Transactions on ecology and The Environment 148. WIT Press, ISSN 1743-3541. DOI=: 10.2495/ RAV110541.

Kizielewicz J and Lukovic T (2013) The Phenomenon of the Marina Development to Support the European Model of Economic Development. The International Journal on Marine Navigation and Safety of Sea Transportation, 7(3), 461-466. 
Lam Gonzales YE, Leon Gonzales CJ, Ledesma JDL (2015a) Highlights of consumption and satisfaction in nautical tourism. A comparative study of visitors to the Canary Islands and Morocco. Gestion y Ambiente 18(1): 129-145. ISSN 0124.177X.

Lam Gonzales YE, Leon Gonzales CJ, Ledesma JDL, Velasquez JAD (2015b) The Canary Islands And Morocco As Destinations For Nautical Tourism. A comparative Approach through Tourists perceptions, Criterio Libre 13(23): 79-97. Bogota (Colombia). ISSN 1900-0642.

Lukovic T (2007) Nautical tourism - definition and classification. Economic Review 58(11): 689-708.

Martinez H (2008) Dictionary for air Travel and tourism activities. New York Bloomington: iUniverse, Inc. ISBN: 978-0-595-52709-0 (pbk).

Mouloudi H (2015) Les ambitions d'une capitale, les projets d'aménagement des fronts d'eau de Rabat. Coll descption du Maghreb, Centre Jacques Berques.

Ministère de l'équipement et des transports (2011) La stratégie portuaire nationale à l'horizon 2030. Publication du Ministère de l'équipement et des transports.

Ministère du Tourisme et de l'Artisanat (2011) Département du Tourisme. Vision 2020. Société Marocaine d'Ingénierie Touristique.

Monqid S (2009) Les morisques et l'édification de la ville de Rabat. Cahiers de la Méditerranée 79: 351-358.

Nachoui M (2014) Les ports marocains: Développement économique et aménagement du territoire. Revue Espace géographique et Société Marocaine 14.

Observatoire du tourisme (2016) Annuaire statistique du tourisme, panorama des performances touristiques au titre de l'année 2015, Ministère du Tourisme.

Péré M (1972) Quelques aspects du tourisme au Maroc à travers l'exemple d'Agadir. Revue de Géographie du Maroc 22: 3-27.

Retière D (2003) Les bassins de plaisance : structuration et dynamiques d'un territoire. Etude comparative Mor Bras (France) - Solent (Grande-Bretagne). Thèse de doctorat, Brest, UBO.

Rieucau J (2000) La Grande-Motte, une ville station touristique. Norois 47(187):341352.

Rutin J (2010) Coastal Tourism: A Comparative Study between Croatia and Tunisia. Tourism Geographies 12(2): 264-277.

Royaume du Maroc (2003) Projet d'aménagement global de la vallée du Bou-Regreg.

Sea Seek (2016) Morocco Atlantic coast, Ebook Sailing guide. NE Atlantic Ocean.

Sbai A, Boumeaza T, Hagelsein S (2005) Impact des actions anthropiques sur le littoral de Saïdia - Cap de l'Eau (Maroc Nord-Est). Colloque national «L'érosion anthropique au Maroc: méthodes d'étude, extension et processus», 23 et 24 décembre 2005, 161-182. Kénitra.

Salmon M, Boumeaza T, Sbai A, Ben Atta M, Ozer A (2010) L'érosion des côtes meubles de l'extrême nord-est du Maroc. Bulletin de la Société Géographique de Liège 54: 97-106.

Signoles et al (2014) Territoire et politiques dans les périphéries des grandes villes du Maghreb. Karthala.

Snoussi M, Ouchani T, Niazi S (2008) Vulnerability assessment of the impact of sea level rise and flooding on the Moroccan coast: the case of the Mediterranean eastern zone. Estuarine, Coastal and Shelf Science 77: 206-213.

UNWTO (2017) Sustained growth in international tourism despite challenges. Retrieved from http://bit.ly/2jHcSdy.

Vellas F, Mehadji Z (2005) Les stratégies touristiques du secteur privé au Maroc. Téoros. Retrieved from http://teoros.revues.org/1521. [Accessed 24 January 2005]. 
Vieville B (1972) La clientèle des ports de plaisance de la Côte d'Azur. Méditerranée 11(3): 19-38.

Wansbrough J (1962) A Moroccan Amīr's Commercial Treaty with Venice of the year 913/1508. Bulletin of the School of Oriental and African Studies 25(3): 450-471. 
